\title{
Jumlah Koloni pada Media Kultur Bakteri yang Berasal dari Thallus DAN Perairan Sentra Budidaya Kappaphycus Alvarezii di Sumenep
}

\author{
Apri Arisandi ${ }^{1}$, Badrud Tamam ${ }^{2}$, Raini Yuliandari ${ }^{3}$ \\ ${ }^{1}$ Program Studi IImu Kelautan, Universitas Trunojoyo Madura \\ ${ }^{2}$ Program Studi Pendidikan IPA, Universitas Trunojoyo Madura \\ 12apri_unijoyo@yahoo.com
}

\begin{abstract}
ABSTRAK
Kappaphycus alvarezii merupakan salah satu rumput laut yang banyak diminta oleh pasar internasional, tetapi saat itu terjadi kegagalan budidaya akibat bakteri pathogen. Penelitian ini berjutuan untuk mengetahui kelompok bakteri apa yang menginfeksi rumput laut (Kappaphycus alvarezii). Penelitian ini dilakukan dengan kultur bakteri yang berasal dari thallus dan perairan pada media PCA, selanjutnya dilakukan pengujian angka lempeng total (ALT). ALT menunjukkan jumlah koloni bakteri yang mendominasi pada suatu media kultur. Hasil penelitian menunjukkan bahwa jumlah koloni bakteri yang berasal dari media perairan lebih tinggi dibanding yang berasal dari thallus Kappaphycus alvarezii
\end{abstract}

Kata Kunci: bakteri, kappaphycus 


\section{PENDAHULUAN}

Pertumbuhan rumput laut dipengaruhi oleh dua faktor yaitu faktor internal dan eksternal. Faktor internal berpengaruh terhadap jenis, galur, bagian thallus dan umur rumput laut. Faktor eksternal berpengaruh terhadap keadaan fisik dan kimiawi perairan. Faktor lain yang dapat mempengaruhi keberhasilan pertumbuhan rumput laut yaitu pengelolaan yang dilakukan manusia. Faktor pengolahan yang perlu diperhatikan seperti substrat perairan dan jarak tanam bibit dalam satu rakit apung (Soenardjo 2003).

Laju pertumbuhan rumput laut berkisar antara $2-3 \%$ per hari. Penelitian penanaman menggunakan rak terapung pada tiga lapisan kedalaman yang berbeda, menunjukkan semakin kepermukaan maka pertumbuhan lebih baik. Hal tersebut karena cahaya matahari merupakan salah satu faktor penting untuk pertumbuhan rumput laut. Rumput laut tidak dapat tumbuh baik jika kedalaman perairan tidak terjangkau cahaya, selain itu iklim, letak geografi dan faktor oceanografi juga menentukan pertumbuhan rumput laut (Aslan 2006).

Kappaphycus alvarezii pada musim-musim tertentu dapat mengalami kerusakan, akibat infeksi bakteri sehingga mengurangi biomass yang dihasilkan. Infeksi penyakit yang terjadi di perairan Sumenep biasanya terjadi sekitar bulan Mei sampai Juli. Penyakit pada rumput laut dipicu oleh perubahan lingkungan yang ekstrim akibat perubahan iklim global sehingga suhu, $\mathrm{pH}$ dan salinitas menjadi sangat fluktuatif. Rumput laut yang stress lebih memudahkan terjadinya infeksi bakteri pada thallus.

\begin{abstract}
Bakteri merupakan mikroorganisme bersel tunggal dengan ukuran panjang 0,5-10 $\mu$ dan lebar 0,5-2,5 $\mu$. Karakteristik bakteri dilihat dari bentuknya, seperti bulat (cocci), batang (spirilli), koma (vibrios). Tambahan struktur bakteri yang terpenting diketahui cambuk (flagella), kapsul (capsule) dan endospora (endospore). Flagella merupakan struktur tambahan diluar sel yang berbentuk cabuk halus yang tidak terlihat di bawah miskroskop kecuali menggunakan teknik perwarnaan khusus. Susunan flagella pada sel yang untuk diidentifikasi dan dikelompokkan menjadi 2 golongan, yaitu flagella peitrichous dan flagella polar (Ansori 2007).
\end{abstract}

Kapsul diperoleh dari gugusan kompleks polisakarida atau polipeptida. Kapsul membuat sel lebih tahan terhadap tekanan lingkungannya seperti panas dan bahan-bahan kimia anti mikroba, dan juga membantu sel melekat pada bahan makanan atau alat-alat pengolahan suatu makanan. Endospora secara umum terbentuk tunggal dalam sel, berfungsi menjaga keadaan lingkungan yang kurang baik. Spora yang sudah masak dilepas oleh sel ke alam sekitarnya, sehingga spora-spora ini bertahan dalam keadaan fisik dan kimiawi yang esktrim seperti suhu, kekeringan, dan bahan-bahan kimia pembasmi kuman dan dpat bertahan dalam keadaan tidur untuk beberapa tahun (Andrito, 2007).

Bakteri memiliki struktur dan organisasi dasar yang sama meskipun dengan bentuk yang berbeda, sel yang terdiri atas lapisan dinding sebagai luar yang kaku dan di bawahnya terdapat membran sel semipermiabel. Di dalam membran sel terdapat suatu isi sitoplasma yang termasuk dalam bahan inti dan 
berbagai komponen serta enzim yang dibutuhkan untuk metabolisme dan pertumbuhan, tergantung pada jenisnya. Bakteri terkadang memiliki struktur tambahan, yaitu diantaranya yang penting adalah cambuk (flagella), kapsul (capsules) dan endospora (endospores), struktur tersebut berpengaruh penting untuk pengenalan dan identifikasi bakteri (Buchanah dan Gibbons, 1974).

\section{METODE PENELITIAN}

Penelitian ini dilaksanakan bulan Juli-Agustus 2015 dengan melakukan pengambilan sampel di sentra budidaya rumput laut Kecamatan Dungkek, Saronggi dan Bluto Kabupaten Sumenep. Pengambilan sampel dilakukan pada lokasi yang berbeda sekitar pukul 12.00 wib. Mengambil sampel air laut dan Kappaphycus alvarezii sebanyak tiga sampel pada masing-masing lokasi. Sampel yang diteliti adalah thallus Kappaphicus alvarezii yang terinfeksi ice-ice dan air laut di lokasi penelitian. Sampel selanjutnya diuji di laboratorium, Pengujian Angka Lempeng Total (ALT) dan tahapantahapan pengujiannya mengikuti panduan yang mengacu pada SNI. 01-2332.3-2006, proses pengujian memerlukan waktu yang cepat dan teliti saat proses pengujian, apabila pada saat pengujian tidak dilakukan dengan cepat dan teliti maka dikhawatirkan sampel akan terkontaminasi dengan bakteri yang ada di lingkungan luar. Sampel rumput laut didapat dari lapang dilakukan pengkodean sesuai dengan standart yang diberlakukan dibalai karantina dan pengujian mutu hasil perikanan Surabaya II (Tabel 1).
Tabel 1. Kodel sampel

\begin{tabular}{lcc}
\hline LOKASI & $\begin{array}{c}\text { RUMPUT } \\
\text { LAUT }\end{array}$ & $\begin{array}{c}\text { AIR } \\
\text { LAUT }\end{array}$ \\
\hline 1. Saronggi & $1389 \mathrm{~A}$ & $1389 \mathrm{~B}$ \\
& $1390 \mathrm{~A}$ & $1390 \mathrm{~B}$ \\
& $1391 \mathrm{~A}$ & $1391 \mathrm{~B}$ \\
\hline 2. Dungke' & $1501 \mathrm{~A}$ & $1501 \mathrm{~B}$ \\
& $1502 \mathrm{~A}$ & $1502 \mathrm{~B}$ \\
& $1503 \mathrm{~A}$ & $1503 \mathrm{~B}$ \\
\hline 3. Bluto & $1613 \mathrm{~A}$ & $1613 \mathrm{~B}$ \\
& $1614 \mathrm{~A}$ & $1614 \mathrm{~B}$ \\
& $1615 \mathrm{~A}$ & $1615 \mathrm{~B}$ \\
\hline
\end{tabular}

Sampel yang terindikasi terinfeksi bakteri dipotong kecil-kecil kemudian ditimbang sebanyak $1 \mathrm{gr}$ dan dimasukkan ke dalam tabung reaksi yang berisi cairan BFP (Butterfields Phosphat) sebanyak 9 $\mathrm{ml}$. Sampel air laut diambil $1 \mathrm{ml}$ dan dimasukkan ke dalam tabung reaksi yang berisi larutan BFP sebanyak 9 $\mathrm{ml}$. Metode kerja pada tahap awal penyiapkan tabung reaksi yang sudah berisi larutan BFP, pada sampel air laut dimulai dari pengenceran 10-0 yang sudah terisi sampel air laut, kemudian diambil 1 $\mathrm{ml}$ dan diletakkan ke pengenceran 10-1 dan dihomogenkan, setelah itu diambil menggunakan pipet kembali $1 \mathrm{ml}$ memasukkan ke pengenceran 10-2, dihomogenkan. Diambil kembali menggunakan pipet dari pengenceran 10-2 dan diletakkan di cawan petri, dilakukan secara duplo. Pengenceran 10-3 dan pengenceran 10-4 dilakukan proses yang sama seperti pengenceran 10-2. Sampel rumput laut dimulai dari pengenceran 10-1 yang sudah berisi sampel rumput laut, diambil menggunakan pipet $1 \mathrm{ml}$ dan dimasukkan pada pengenceran 10-2 dihomogenkan, diambil $1 \mathrm{ml}$ dari pengenceran 10-2 kemudian diletakkan pada cawan petri secara duplo. Diambil 
menggunakan pipet $1 \mathrm{ml}$ pengencer 10-2 dan diletakkan pada pengenceran 10-3 dan dihomogenkan, kemudian dari pengencer 10-3 diambil menggunakan pipet $1 \mathrm{ml}$ dan diletakkan pada cawan petri, secara duplo. Proses ini dilakukan secara sama sampai pada pengenceran 104. Menuangkan media PCA ke dalam cawan petri yang berisi sampel dan larutan BFP dari proses pengenceran sebelumnya. Menuangkan larutan PCA pada masing-masing cawan petri dan dihomogenkan agar media PCA dengan sampel tercampur rata. Ditunggu sampai PCA padat, pada saat PCA sudah padat maka cawan petri dibalik, dan diletakkan dalam inkubator selama 24-48 jam dengan suhu 370C (Rasika, et al., .2012). Data hasil uji-uji tersebut selanjutnya dianalisis secara deskriptif.

\section{HASIL DAN PEMBAHASAN}

Angka Lempeng Total (ALT) merupakan salah satu cara untuk mempermudah dalam pengujian mikroorganisme dari suatu produk, dan Angka Lempeng Total (ALT) menunjukan adanya mikroorganisme pathogen atau non pathogen yang dilakukan pengamatan secara visual atau dengan kaca pembesar pada media penanaman yang diteliti, kemudian dihitung berdasarkan lempeng dasar untuk standart test terhadap bakteri (BPOM 2008).

Hasil dari perhitungan Angka Lempeng Total (ALT) pada sampel rumput laut dan sampel air laut diperoleh nilai ALT; Desa Tanjung Kecamatan Saronggi hasil ALT tertinggi pada sampel rumput laut 1389 A (Saronggi) dan sampel air 1389 B (Saronggi) dengan nilai ALT sebesar 1,9. $104 \mathrm{kol} / \mathrm{gram}$, dan 1,8.105 kol/gram. Angka terkecil pada sampel rumput laut $1390 \mathrm{~A}$ (Saronggi) dengan hasil ALT sebesar 1,3. $104 \mathrm{kol} / \mathrm{gram}$. Lokasi kedua di Desa Dungke' Kecamatan Dungke' didapatkan hasil perhitungan jumlah koloni ALT terbesar terdapat pada sampel rumput laut 1503 A dengan hasil 2,6. $106 \mathrm{kol} / \mathrm{gram}$, dan nilai ALT yang terkecil 3,2. $105 \mathrm{kol} / \mathrm{gram}$ pada sampel rumput laut $1501 \mathrm{~A}$, kemudian pada sampel air di lokasi Dungke' perhitungan koloninya mengalami TBUD (tidak bisa untuk dihitung). Data terakhir pada lokasi pengambilan sampel di Desa Aengdakeh Kecamatan Bluto diperoleh hasil perhitungan ALT tertinggi yaitu $1,4.107 \mathrm{kol} / \mathrm{gram}$ dengan sampel rumput laut $1614 \mathrm{~A}$, sedangkan perolehan hasil terendah pada sampel rumput laut $1613 \mathrm{~A}$ dan nilai ALT yaitu 1,9. $104 \mathrm{kol} / \mathrm{gram}$ (Gambar 1).

Teurupun et al. (2013) menyatakan bahwa hasil suatu perhitungan koloni kapang pada rumput laut kering yang diinkubasi selama 7 hari dengan menggunakan suhu inkubator $300 \mathrm{C}$ selama 3, 5 dan 7 hari dapat diperoleh data jumlah hasil koloni kapang pada rumput laut kering. Hasil data perhitungan total koloni yang diperoleh antara 2,0 x

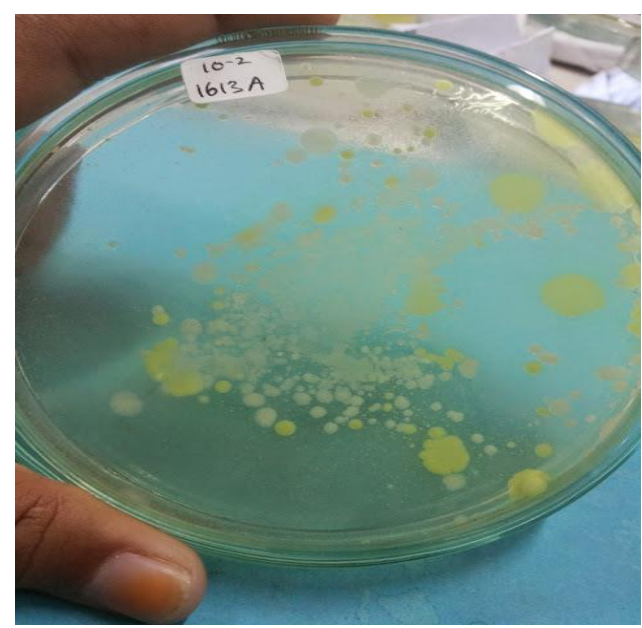

Gambar 1. Koloni bakteri. 
$103-3,0 \times 103 \mathrm{kol} / \mathrm{gram}$, kemudian total koloni tertinggi diperoleh sebesar 3,0 x $103 \mathrm{kol} / \mathrm{gram}$.

Hasil perhitungan ALT sesuai dengan hasil perhitungan pada sampel air laut dan rumput laut yang terjangkit ice-ice yaitu hasil ALT tertinggi diperoleh pada sempel rumput laut $1501 \mathrm{~A}, 1390 \mathrm{~A}$ dan 1614 $A$ yang berada pada masing-masing lokasi sebesar 1,3.104-1,4.107 $\mathrm{kol} / \mathrm{gram}$, sedangkan pada sampel air laut nilai ALT tertinggi antara kisaran 1,8.105-2,5.106 kol/gram pada masing-masing lokasi. Berbeda dengan hasil pada sampel air laut yang terdapat beberapa sampel TBUD, hal tersebut dimaksudkan hasil perhitungan melebihi batas maksimum \pm 350 koloni/jumlah koloni bakteri yang tak hingga. Hasil perhitungan koloni ditemukan jumlah koloni yang sama antara bakteri yang terdapat di rumput laut dan di air lautnya pada sampel 1389 di Desa Saronggi sebesar 1,8.105 kol/gram. Sedangkan jumlah koloni di rumput laut lebih banyak dari pada di air lautnya ditemukan pada sampel dilokasi Bluto, dengan nilai di rumput laut sebesar 1,4.107 kol/gram, sedangkan di air lautnya sebesar 2,2.105 kol/gram. Hal ini menunjukkan tingkat infeksi dari bakteri yang ada disampel rumput laut lebih besar dibandingkan dengan jumlah bakteri dimedia hidupnya, yaitu diperairan.

Lokasi Dungke' terdapat nilai ALT yang sampai hasil perhitungan melebihi batas maksimum \pm 350 koloni/jumlah koloni bakteri yang tak hingga, pada sampel air laut, sedangkan untuk nilai terkecil pada sampel rumput laut dengan nilai ALT yaitu 3,2.105 kol/gram. Tetapi pada lokasi Saronggi dan Bluto terdapat pula jumlah koloni tertinggi pada sampel air laut dibandingkan dengan sampel rumput laut yang lebih kecil.
Hal tersebut sesuai dengan pernyataan dari Irianto (2003) yang menjelaskan bahwa hal ini dapat terjadi dikarenakan adanya kompetisi nutrisi dan tempat perlekatan pada dinding intestinum. Sehingga adanya aktifitas kompetisi dan penekanan pada mikroorganisme yang disebabkan bakteri memiliki sifat antagonis terhadap yang berada di dalam perairan dengan menghasilkan suatu enzim protease (Gusminarni 2009).

Infeksi bakteri akan bertambah berat akibat serangan epifit yang menghalangi penetrasi sinar matahari, sehingga tidak memungkinkan thallus rumput laut melakukan fotosintesis. Menurut Yulianto (2002) rumput laut yang terserang bakteri ditandai dengan: Memutihnya atau memudarnya warna batang (thallus); Berlendir yang diselimuti oleh kotoran seperti tepung putih; Kulit luar atau epidermisnya terkelupas pada yang terinfeksi sehingga terlihat jaringan dalam atau medula pada thallus.

Awal terinfeksi pada thallus dimulai dari bagian tertentu, yaitu: Infeksi bermula dari bagian luka pada pangkal stek akibat dari pemetikan; Infeksi bermula dari bagian yang luka pada bekas gigitan predator ikan; Infeksi dimulai dari bagian yang luka karena gesekan yang terlalu erat dan mengikat rumput laut; Infeksi akibat tertularnya bagian batang yang sehat oleh bagian batang yang terinfeksi dari satu rumpun atau rumpun berasal dari rumpun yang lain.

Menurut Ansori (2007), pengaruh terhadapat pertumbuhan mikroorganisme untuk hidup dipengaruhi oleh beberapa faktor, yaitu:
a) Suplai gizi
Suatu
mikroorganisme membutuhkan suplay makanan yang menjadikannya sumber 
energi dan menjadikan unsurunsur kimia dasar sebagai pertumbuhan selnya. Unsurunsur tersebut adalah karbon, hydrogen, oksigen, sulfur, fosfor, magnesium, zat besi, dan sejumlah logam kecil lainya.

b) Temperatur

Temperatur merupakan faktor penting untuk kehidupan, ada beberapa jenis mikroba yang dapat hidup di daerah temperatur yang luas, dan sebagian mikroba lainnya berada pada temperatur yang terbatas. Mikroba hidup pada kisaran temperatur $0-90 \stackrel{\circ}{\circ}$. Hubungan antara suhu dan mikroorganisme digolongkan menjadi 3 golongan utama, yaitu; Kelompok Psikofilik (oligotermik). Mikroba psikofrolik adalah mikroba yang bisa tumbuh pada kisaran suhu antara $0-30 \quad \stackrel{\circ}{ }$, dengan temperatur optimum antara 10$15^{\circ} \mathrm{C}$, dari golongan ini tumbuh pada tempat dingin, antara daratan maupun lautan; Kelompok Mesofilik (mesotermik). Mikroba mesofil adalah mikroba yang dapat hidup dengan baik pada temperatur 5-60 ${ }^{\circ} \mathrm{C}$, kemudian pada temperatur optimum berkisar 25-40 $\stackrel{\circ}{ } \mathrm{C}$, dan dapat hidup dalam pencernaan; Kelompok Thermofilik. Mikroba thermofil adalah mikroba yang dapat tumbuh pada temperatur 40-80 $\cong$, sedangkan temperatur optimumnya antara 25-65 $\stackrel{\circ}{ }$. Golongan thermofil terdapat pada tempat sumber-sumber air panas dan tempat yang bertemperatur tinggi.

\section{c) $\mathrm{pH}$ (potensial Hidrogen)}

Mikroorganisme bisa tumbuh pada $\mathrm{pH}$ antara 6,0 - 8,0 dan nilai pada $\mathrm{pH}$ diluar kisaran 2,0 - 10,0 yang bersifat merusak. Menurut Dewiana (2008), dasar-dasar daerah $\mathrm{pH}$ untuk kehidupan mikroorganisme dibedakan 3 golongan besar, antaranya; Mikroorganisme asidofilik, mikroba yang tumbuh pada $\mathrm{pH}$ 2,0 - 5,0; Mikroorganisme mesofilik, mikroba yang tumbuh pada $\quad \mathrm{pH} \quad 5,5-8,0$; Mikroorganisme alkalifilik, mikroba yang tumbuh antara $\mathrm{pH}$ $8,4-9,5$.

\section{SIMPULAN}

Jumlah koloni bakteri yang berasal dari media perairan lebih tinggi dibanding yang berasal dari thallus Kappaphycus alvarezii.

\section{UCAPAN TERIMA KASIH}

terimakasih kepada Direktorat Pendidikan Tinggi Kementerian Riset Teknologi dan pendidikan Tinggi yang telah memberikan dana penelitian fundamental tahun 2016 sehingga artikel ini dapat terselesaikan.

\section{DAFTAR PUSTAKA}

Andrito, W., 2007. Karaterisasi molekuler bakteri probiotik pada saluran skrining bakteri Vibrio Sp asli Indonesia. Pencernaan ikan kerapu bebek (Chromileptes altivelis) Berbasis Teknik 16 S rDNA. Skripsi, Faperika Universitas Riau. 
Ansori M. 2007. Analisa Jumlah Bakteri dan Keberadaan Esoherichis Coli Pada pengolahan ikan teri nasi Stolephosus spp di PT. Kelola Mina Laut Unit Sumenep. Universitas Trunojoyo Madura.

Aslan LM. 2006. Budidaya Rumput Laut. Konisius. Yogyakarta. 97 hal.

Buchanah, R.E. and Gibbons, N.E. 1974., Bergey's manual of determinative bacteriology 8th edition. Baltimore: The Williams and Wilkins Company.

[BPOM]. Badan Pengawas Obat dan Makanan. 2008. Angka Lempeng Total (ALT).www.pom.go.id/ Diakses [14 Desember 2014]. Irianto A. 2003. Probiotik Akuakultur.Cetakan I.Penerbit Gadjah Mada University Press. Yogyakarta. 125 hal.

Rasika, C., Torane, Gayatri, S., Kamble,Swati, M., Devare, Usha, D., Phalgune, Nirmala, R., Deshpande., .2012.
Isolation and characterisation of 1,2 benzenedicarboxylic acid, bis (2 ethylhexyl) ester dioctyl phthalate, a bioactive compound from Ehretia laevis. Jof Pharma Research, 5(6), 3251-3252.

Soenardjo. 2003. Membudidayakan Rumput Laut. Balai Pustaka Semarang.

Teurupun A, Samuel M, Timbowo, Joyce. 2013. Identifikasi Kapang Pada Rumput Laut (Kappaphycus alvarezii) Kering Dari Desa Rap Rap Arakan Kecamatan Tatapan Kabupaten Minahasa Selatan. Universitas Sam Ratulangi. Perikanan dan IImu Kelautan. Manado. Vol 1(1). Hal (14-15).

Yulianto K. 2002., Pengamatan penyakit ice-ice dan alga kompetitor Fenomena kegagalan panen pada rumput laut di Pulau Pari dan Kabupaten Seribu. Tahun 2000 dan 2001. Pusat Penelitian Oseanografi Lipi. Jakarta. Hal 2-4. 